\title{
The Transnationalization of European Television
}

\section{ANDREA ESSER}

It is commonly acknowledged that a European dimension has come to exist in television as far as media legislation is concerned and that media players have increasingly been operating in a cross-border fashion since the introduction of private commercial broadcasting and satellite transmission in the 1980s. Even so, the majority of scholars and media practitioners emphasize that 'television without frontiers' has not become a reality. National markets and audiences, they argue, are persistent. ${ }^{1}$ Since the late 1980 s, a number of studies have been undertaken to compare various European countries with regard to their television systems, to describe the development of media policy at the European level, or to study the operation of pan-European television channels. All of the the latter concluded by highlighting the apparently insurmountable obstacles of language and differing national mentalities to the creation of a 'European television market.' The comparative studies noted that, first, terrestrial, and thus basically national, transmission still plays a major role; second, the development of cable and satellite distribution has been very unequal across Europe; and, finally, national television channels still have the highest audience ratings. ${ }^{2}$

This article contests this conventional view regarding the dominance of the national framework in European television. ${ }^{3}$ In the first instance, the term 'national channel' has become questionable in itself. Several channels in Europe have been and still are very popular in small neighbouring countries with the same

\footnotetext{
${ }^{1}$ In interviews with media professionals this was the consensus view. See also, Ingrid Scheithauer, 'Medienordnung ', Frankfurter Rundschau, 29 November 1997; François Godard, 'The power of four ', Television Business International, June 1993, pp. 22-24; Uwe Hasebrink, 'Fernsehen und Hörfunk in Europa ', in: Hans-Bredow-Institut, Internationales Handbuch für Hörfunk und Fernsehen, 1996/1997, Hamburg 1996, Part A, pp. 64-82.

${ }^{2}$ See, for example, P. J. Humphreys, Mass Media and Media Policy in Western Europe, Manchester 1996; Julian Petley and Garbriella Romano, 'After the deluge. Public service television in western Europe ', in: T. Dowmunt, Channels of resistance. Global television and local empowerment, London 1993; Anthony Weymouth and Bernard Lamizet, Markets and Myths. Forces for change in the European media, London 1996.

${ }^{3}$ This article is based on research undertaken for a PhD thesis: Andrea Esser, The Transnationalisation of Television in Europe: 1985 -1997, London, South Bank University 2001.
} 
language. Moreover, it is debatable the extent to which newly launched channels usually built around cheap imported programmes and set up by international teams can be justifiably defined as 'national '. In addition, although terrestrial transmission still played a major role in the majority of European countries in the 1980s and 90s, it is also the case that national markets have increasingly been losing their homogeneity due to growing cable and satellite distribution and reception. Residency and national identity alone no longer determine who watches what. Finally, it seeems evident that the offering of pan-European and satellite channels in general have led to a redrawing of viewing communities throughout Europe and across its national frontiers.

As is the case with many other industries, the television industry has undergone a process of transnationalization - defined here as 'the increasing transborder flow of services and programmes and the increased exposure of audiences to an imported media culture ', ${ }^{4}$ combined with the growing participation of nonnational entities in broadcasting. The term transnationalization we consider more appropriate than the frequently employed terms internationalization and globalization. The process in broadcasting, as in many other sectors, has not been an evenly distributed pattern but a much more complex and irregular configuration. From a geographical point of view, different countries in Europe reacted differently to non-national forces, depending on the size and traditional interest in the media in general or the production sector in particular; and Western European countries expanded into Central and Eastern Europe but not viceversa. With regard to the field of activity, it was especially American companies that had considerable impact and power in the audio-visual distribution and production sectors and influence with respect to programming techniques. The term transnationalization, therefore, better reflects the uneven pattern of the phenomenon of the world-wide expansion of companies and their offerings.

Set off by the concurrence of new broadcasting transmission technologies with a changed ideological climate, it is argued here that a major re-structuring of the traditional broadcasting architecture all over Western Europe took place in the 1980s and 90s. This included media policy, ownership, channel offerings, programming and consumption. Satellite transmission ended the limitation of airwave space and enabled broadcasters to transcend national frontiers almost without limits. Private commercial television broadcasters came into existence and started to set up channels on the European continent. Non-national investors began to acquire stakes in national private television stations. A European television market came into existence, albeit not as predicted in the 1980s, i.e. determined by pan-European television channels, but more by European and American media agents broadcasting via localized outlets to countries and language areas. Especially during the 1990s it was a 'glocalization "5 trend that

\footnotetext{
${ }^{4}$ Denis McQuail, 'Western European media. The mixed model under threat ', in: J. Downing et al., Questioning the media. A critical introduction, London 1995, p. 159.

5 'Glocalisation ' is a Japanese formulation coming from dochakuka, roughly meaning 'global localisation. ' Roland Robertson has introduced the term to globalisation theory in respect to culture.
} 
determined the development of television in Europe. Local diversification was not a step back, but rather a modified means to continue the transnationalization process.

It is further argued that it was private, commercial media agents who provided the major impetus to, and a shift of emphasis within, the European media structure. ${ }^{6}$ In fact, the trends towards transnationalization and commercialization correlated. While it was the commercial sector which provided the dynamic for transnationalization in Europe, transnational operations of companies enforced the introduction of commercial television in those national markets that resisted the new commercial approach to broadcasting. By the end of the 1990s, the essential structural changes were more or less completed. The next generation of channels already belonged to the thematic group, distributed via satellite or cable only, and the duopoly of public service and private commercial broadcasters had become firmly established - with, however, the standing of the public service broadcasters gradually losing ground.

With the inauguration of digital television in Europe, the television landscape was again to change considerably. Pay-TV was gaining in importance, and digital technology was opening up more refined possibilities for transmission, including transnational. Regional opt-outs, multiple language tracks, or timeshifted transmissions were becoming more feasible. Moreover, the development of financing was to further the transnationalization of television ownership. Following their American competitors, European media companies increasingly entered the stock market. While in 1990 not one single media enterprise in Europe was listed, in 1998 there were about 50 and the trend has continued since. Should national governments come to find it desirable to reverse or at least check the commercialization and transnationalization of television, the single market and the ongoing harmonization of laws will render it nearly impossible. In addition, the force of the private commercial television industry, as has been the case in other industries, has constantly increased. While the history of television 's transnationalization demonstrates that the private commercial television industry has been able to push media policy in the direction it desired from the start, its influence in the digital future is likely to be even greater.

The regulatory philosophy of media laws to date will certainly come unstuck when faced by the globally structured multimedia and information society of the future. The actors in this environment can move with relative ease from one level and sphere of action to another, disguise themselves through structural interlocking, submerge in international networks or openly risk power

\footnotetext{
${ }^{6}$. R. Negrine and S. Papathanassopoulos, The internationalisation of television, London 1990, and P. J. Humphreys and K. Dyson, Broadcasting and new media politics in Western Europe, London 1988, stress that the changes were a product of new political and economic ideologies. However, they do not highlight the industry itself as a very important driving force.
} 
struggles with supervisory bodies - and usually win on account of the numerous dependencies. ${ }^{7}$

To show that the private commercial industry has in fact been a major driving force for the transnationalization of broadcasting in Europe, to lay open the extent transnationalization reached in the 1980s and 90s and to display the means employed during the latter decade, namely glocalization, this article looks at three specific areas of transnationalization: ownership, the channel landscape and programming. Following the first section which provides a brief historical introduction, in the second section we analyze the most important European and American broadcasters involved in the transnationalization of television. The third section examines pan-European channels and other transnational channel offerings in Europe. In the fourth section the transnationalization of programming will be looked at from three angles: Europe 's largest common denominator, American fiction; the transnational expansion of European productions; and internationally shared formats and genres. Finally, in the conclusion to the article, the debate on socio-cultural consequences and identity will be addressed.

\section{Towards a transnational television market}

From the Second World War onwards, in the vast majority of Western European countries a public service ethos had provided the normative framework for broadcasting, which was organized on a national basis using terrestrial means of transmission. There had been some transnational activities, run under the auspices of the European Broadcasting Union (EBU). The institutionalized exchange of programmes between the EBU 's members, the so-called Eurovision, had established itself over the years and become an indispensable programme source, particularly for broadcasters from small European countries. However, while this exchange of programmes from national public service broadcasters was seen as culturally desirable, and a natural over-spill of terrestrial transmissions had never been considered a problem, deliberate transmission by commercial broadcasters to neighbouring countries was not welcome. As early as the 1920 s and 30s, when 'unauthorized ' radio services, financed by advertising from English businesses, transmitted English language programmes from France to the UK, strong reactions had been provoked because governments feared they would lose control over public opinion.

The first commercial television broadcasting activities had been introduced in the 1950s in Luxembourg, the UK and Monaco. The UK had added ITV 'to shake up the BBC ', 8 , while Monaco and the Duchy of Luxembourg had never established a public service broadcasting system due to their small size and, in the case of Luxembourg, linguistic diversity. From the beginning of broadcasting, the Luxembourg franchise was given to a private company, Compagnie

\footnotetext{
${ }^{7}$ Wolfgang Hoffmann-Riem, 'New challenges for European multimedia policy. A German perspective ', European Journal of Communication, Vol. 11, No. 3/1996, p. 330.

${ }^{8}$ A. Weymouth, 'The Media in Britain ' in: Weymouth and Lamizet, p. 62.
} 
Luxembourgeosie de Télédiffusion (CLT). However, the company did not restrict its broadcasting activities to the Duchy. Right from the start in 1954, it exploited terrestrial over-spill by aiming its programmes at the neighbouring French region of Lorraine. With the assignment of satellite channels at the WARC conference in 1977, CLT 's potential reach expanded, enabling it to develop private television channels for other European countries where private commercial television was still prohibited.

The previously purely national character of broadcasting policy was affected. No longer could broadcasting regulation be introduced and carried out regardless of what happened elsewhere in Europe. A European dimension came to be added to broadcasting policy. In 1980, the Debauve judgement opened the way for Article 59 of the EC treaty in relation to the free circulation of programmes across the Community. In 1981, the Parliamentary Assembly of the Council of Europe adopted a recommendation (No. 926) on 'Questions raised by cable television and by direct satellite broadcast. ' In the individual European countries media legislation, too, began to consider the new environment. For example in 1981 in Germany the FRAG judgement established guidelines for the expansion of West German broadcasting that might result from new technologies like cable and satellite. Meanwhile, in France the Moinot Commission Report demanded a radical transformation of French broadcasting with the aim of creating a free market while at the same time retaining state control through a system of licensing. Legislative change also reflected an altered ideological climate. The opportunities that cable and satellite technology had opened up in the 1970s fitted well with a general ideological shift towards a neo-liberal economic policy in the majority of Western European countries. By the beginning of the 1980s, a commercial importance had attached itself to the development of new communications technology, and decisions concerning broadcasting came to be taken in an industrial policy framework.

Even so, liberalizing re-regulation took time to be implemented. It became established practice for national regulatory bodies to supervise private commercial activities. Where liberalization was viewed with suspicion, cross-border activities of private entrepreneurs pushed it along. Luxembourg and the UK became 'commercial television havens, ' enabling broadcasters to circumvent national media regulations of third countries. Where nation states tried to retain control over their cable networks, the European Court of Justice ensured that crossborder transmission was not prevented. Driven by activities from outside their frontiers, gradually all Western European countries came to permit private commercial broadcasting. National governments and regulatory bodies wanted control over broadcasting offerings in their home country, and they preferred advertising revenues to stay in their country and employment to be created there. For the broadcasters, on the other hand, a favourable relationship with the governments and regulatory bodies of the countries targeted was advantageous in respect to terrestrial and cable distribution. In October 1994, the European Court of Justice made it clear in its verdict on the Dutch case, Commissariaat 
voor de Media versus TV 10, that a broadcaster was not allowed to establish itself in another member state of the EU in order to circumvent national media regulation of the country or countries it intended to target. Increasingly therefore channels were set up within the borders of these countries, usually in the form of joint ventures with indigenous partners due to restrictions on ownership, but also because the latter provided valuable local know-how.

\section{Transnational companies}

At the forefront of transfrontier broadcasting was the CLT. Its number of television stations grew from 1 in 1984, to 4 in 1987, 7 in 1990 and 13 in 1995, making it Europe 's free-TV market leader. Not only was its network by far the largest, but many of its television channels were well placed in terms of audience and advertising market shares. Where a general interest channel had been successfully established, as for example in Germany, the Netherlands and Belgium, secondary channels were launched to consolidate the group 's market position. According to the CLT, which also owned over 20 radio stations, by 1996 the RTL logo was familiar to two out of every three Europeans. By the end of 1997 the new group CLT-UFA, the outcome of a merger between the CLT and Bertelsmann 's subsidiary UFA, was involved in 22 television channels in nine European countries (with major audiences in eleven). ${ }^{9}$ In 2000, CLT-UFA completed its merger with Pearson Television, creating a publicly traded company, the RTL Group, with a market capitalization of 2.5 billion Euros. The merger gave a powerful boost to CLT-UFA 's role as a producer of programmes and thus strengthened its overall market position through enhanced vertical integration. The transnational approach of the RTL Group was highlighted again in March 2002, when chief executive Didier Bellens announced that the group intended to foster its growing together by directly exchanging top executives. ${ }^{10}$ Quickly following in the footsteps of the CLT were Berlusconi 's Fininvest Group in Italy, the Maxwell Corporation in the UK and Canal+ in France. Canal+ and Fininvest had become powerful players at the national level and as a result wanted to expand beyond their respective national borders. Canal+, Europe 's pay-TV market leader, had begun transmissions in France in 1984. Safeguarded by the French state, only two years later it had reached break-even

\footnotetext{
${ }^{9}$ The biggest station in terms of turnover and profit came to be RTL in Germany, contributing more than half of the group 's television turnover by reaching close to 34 million Germanspeaking households in Germany, Austria, Switzerland and Luxembourg. Apart from the fully owned RTL, the company participated in German-language general interest channels VOX and RTL2 and in the family-entertainment channel Super RTL. In the Netherlands, the CLT had a majority share in RTL4 S.A., where RTL4, RTL 5 and later RTL Veronica made up the Holland Media Group. In France, the company was involved in M6 and RTL9. In French speaking Belgium the CLT ran RTL TVi and its subsidiary Club RTL. The company 's later investments in general interest channels included Poland, (RTL7 1996), the UK (Channel 5 1997) and Hungary (RTL Klub 1997). In addition to these major free-to air channels the company had interests in French subscription services, the French digital platform TPS, the German pay-TV channel Premiere, the Monte Carlo channel TMC and the Luxembourg channel RTL Hei Elei.

${ }^{10}$ Handelsblatt, 14 March 2002.
} 
point. In 1988, the company received permission from the Higher Belgian Audio-Visual Council to broadcast in Belgium. In the following decade, teaming up with leading local media partners the company began 'exporting its proven format ${ }^{\text {"11 }}$ to other countries: Spain (Canal+ España, 1990), Germany (Premiere, 1991), French-speaking Africa (Canal Horizons, 1991), and Poland (Canal+ Polska, 1995). In April 1997, Canal+ merged with Europe 's other big pay-TV network, Filmnet, and now covered the whole of Western and much of Central Europe. While Fininvest and Maxwell due to money-losing investments in the first case and industrial resistance in the second - had eventually given up their European ambitions, the CLT and Canal+ had expanded further and further geographically, gradually leaving the more familiar neighbouring territories behind. This became especially marked in the 1990s, when Central and Eastern European television markets without cash-rich home players suddenly opened up - an opening that also provided American companies with greater opportunities to move into European broadcasting.

American broadcasters with the strongest presence in Europe in the 1980s and 90s were also among the internationally largest and most fully integrated media operators: Time Warner, Disney, Viacom and News Corporation. Together with the newly established Central European Media Enterprises, which was of importance in Central and Eastern Europe, their European activities accelerated the process of transnationalizing Europe 's television markets. In this context we shall restrict ourselves to highlighting just a few of their activities. AustralianAmerican Rupert Murdoch, who in his many attempts to enter the continental European television markets had frequently come against angry responses, by the end of the twentieth century had controlling interests in BSkyB and two small German free-to-air channels, Vox and tm3. Fox Kids Europe had launched children 's channels in eleven European countries, while in Italy Murdoch had acquired a major stake in the digital platform Stream. Disney 's involvement as a broadcaster in Europe included the Disney pay-TV channels in the UK, France, Germany, Italy and Spain, as well as participations in Eurosport, German channels Super RTL and RTL2, UK television licence holder GMTV and Scandinavian Broadcasting Systems (SBS). SBS had started launching channels in early 1990 in the developing Scandinavian commercial television market (Kanal5, a UK licensed channel for Sweden, TV Norge in Norway and TV Denmark) and then expanded to Belgium (VT4, a UK licensed channel), the Netherlands (SBS6), Hungary (TV2), Italy (infomercial channel Retemia) and Slovenia (Kanal A). Ted Turner, on the other hand, had begun his European offensive in 1985 with CNN. Later he acquired a controlling stake in the German news-channel n-tv. He also launched TNT \& Cartoon Network all over Europe, with several dubbed or subtitled language strands. Time Warner, which also had a stake in n-tv, established itself in Central Europe with its payTV operation HBO, participated in Scandinavia 's pay-TV channel TV 1000,

${ }^{11}$ Canal+, Annual report 1995, Paris 1996, p. 0 
Spain 's pay-TV channel Cinemax, the German music channel VIVA/VIVA2, local channels in Berlin and Hamburg, and in the French Canal Satellite.

In terms of market share, however, these American investments were of lesser significance than those of CLT-UFA and Canal+, and of course the terrestrial channels of any national broadcaster. Moreover, not all American activities in Europe proved successful. Disney decided to sell its stake in SBS at the beginning of 1998, General Electric sold 50\% of NBC Europe to BSkyB to turn the programme into the National Geographic Channel, and some smaller American broadcasters closed down their European activities altogether. ${ }^{12}$ In contrast, both the German Bertelsmann AG with CLT-UFA and the French Vivendi (created in March 1998 when Compagnie Générale des Eaux took over Havas, a controlling shareholder of Canal+) had developed into powerful European media conglomerates. In 1998 the Italian media company Fininvest, which had dreamt of a pan-European network in the 1980s but had concentrated more on its home market after a few money-losing investments abroad, acknowledged the need for a transnational orientation. Since then the 'size matters ' formula has not lost its significance. In October 2000, several top European television executives voiced their opinion that expansion had not yet come to an end. Bellens said, 'Today, the size of the European groups is much bigger, but when we compare them on a world-wide basis, we still have to grow and develop. I strongly believe we cannot stop our expansion. We have to keep growing. ${ }^{13}$

\section{Transnational channels}

Satellite technology not only reduced the shortage of airwave space, thus enabling a greater number of television channels to transmit within countries, but rendered possible pan-European broadcasting. The latter had come to be desired for commercial reasons as well as the integrative aims of the EU. In addition to truly pan-European channels, satellite-distributed channels in languages that were shared by several countries contributed much to transnationalizing television in Europe and thereby creating a European market. In the pan-European market, after the apparent failure of the earliest attempts, namely Satellite TV (1982) and Super Channel (1986) which had both resumed transmission as general interest channels in English, a move to thematic channels occurred. Some special interest channels adhered to English as the lingua franca. But with rising competition, a trend towards offering dubbed and subtitled versions started. Moreover, those thematic services which faced local competition began to integrate local programme windows as defence strategies, especially evident in the case of music, sports and news channels.

The example par excellence for the development of pan-European channels is MTV Europe. Launched in August 1987, it used English as the lingua franca,

\footnotetext{
${ }^{12}$ Gaylord Entertainment closed down its Country Music Television service in March 1998. Landmark Communications closed down The Weather Channel in the UK, the Benelux, Germany, Italy, and Scandinavia.

${ }^{13}$ World Screen News, October 2000, p. 63.
} 
arguing that the transmission of video clips was less dependent on language. Moreover, MTV claimed, the 'universal language of music ' was English. The channel attained cult status in many European countries. However, its success attracted local competition: in Germany with VIVA and Onyx, MCM in France, The Music Factory in Holland, The Box in Britain, Videomusic/TMC2 in Italy, Tylko Muzyka and Atomic TV in Poland and Z+ in Hungary. All these services competed with MTV not only for advertising revenue, but also for space on cable networks. In both areas they quickly overtook MTV. In 1996, MTV finally admitted that its only chance to counteract local competitors was through the diversification of its own service at local level. Thanks to enormous technical expenditure, viewers in Europe could now be provided with three different regional feeds (north, middle, south) via digital compression. Moreover, in March 1997 a German-language version was launched.

Working with a multi-lingual approach from the start were Euronews, broadcasting from 1993 in five languages, and Eurosport, which resumed broadcasting in 1989 in English, Dutch and German. Eurosport proved successful, but as with MTV, local competition was on the increase and the channel began setting up programme windows for the encrypted Nordic and French direct-to-home satellite services. In 1997, 'Belgian windows ' were created with the public service broadcaster RTBF transferring its sports coverage to Eurosport. More local windows were to follow. At the beginning of 1998, Eurosport, the largest thematic channel in Europe, could be received in 46 countries in 15 different languages, reaching a daily average of about 17 million viewers.

Yet other thematic niches attempted via a pan-European approach were that of children 's programming with, for instance, TCC, an encrypted channel with the majority of its programmes coming from the United States and a quarter of programmes subtitled in Danish, Dutch, Norwegian and Swedish; or the Cartoon Network, launched with dubbed or sub-titled language strands in English, French, Spanish, Italian and Swedish. The documentary niche was occupied by Discovery Communications Inc., which launched its first European venture in 1989 to households in the UK and Scandinavia. By 1997, Discovery Channel had an overall penetration of 13 million households in over 30 European countries. The service broadcast in English but offered subtitles for a major part of its programme output in Danish, Dutch, Finish, Norwegian, Swedish, Italian, German, Polish, Hungarian, and Romanian. Since then, both penetration figures and the number of language versions have increased enormously. Today Discovery Europe reaches 32 million households in 20 different dubbed or subtitled language versions.

In the 1990s, the majority of people in the media industry came explicitly to emphasize the importance of local resonance and all channels underwent some process of local diversification. ${ }^{14}$ A number of soundtracks came into existence,

\footnotetext{
${ }^{14}$ Note that the term local television is not used here in its traditional function, as an antonym to national television, but in its network role, as an antonym to international, European or national television.
} 
some local productions were included in each outlet, and scheduling varied a little. Even so, much of the programming was shared by the various outlets. Joyce Taylor, Chief Executive of United Artists Programming, who was managing Discovery 's European operations at the time, argued that this was no great departure, but just a "watered-down version of the pan-European ideal. ${ }^{15}$ The local approach concerned not just programming, but also advertising. It was an advantage to be able to provide international advertisers with a far-reaching distribution, while at the same time being able to offer less expensive local optouts to companies without international brands. First, there were still too few international brands to finance more than a dozen pan-European theme channels with a restricted audience. Second, with European coverage still posing problems due to saturated cable networks and direct-to-home distribution facing as yet unresolved technical problems, potential European audience figures were unlikely to proliferate in the immediate analogue future.

A second transnational broadcasting approach was that of general interest channels targeting language areas or language groups. This not only avoided the language problem, but it also had the advantage that programme rights could be acquired more cheaply. While pan-European channels had to pay for international rights, language-area channels had to pay only for the specific language area. Language area channels strengthened as a result of satellite distribution and, in terms of audiences, they were in the vanguard in creating a European market. The RTL channels of the CLT are good examples of how German- and French-language channels were not only popular with viewers in Germany and France respectively but also in Austria, Switzerland, Luxembourg and Belgium. In general, programmes shown in linguistically consonant neighbouring countries had a very high share of overall viewing. In the three Swiss language areas they even had a higher audience rating than the output of the indigenous channels; in Austria, the period from 1993 to 1996 saw foreign networks increase their daily reach from $34 \%$ to $39 \%$; and French channels continued to attract audiences in southern Belgium, drawing a combined 33\% market share in $1997 .^{16}$

In addition to these satellite-distributed general interest channels in European languages, ethnic channels, set up by non-European broadcasters and targeting groups of immigrants and ethnic minority communities of non-European origin, came to be firmly established. Media journalist Nick Bell rightly pointed out 'the beauty ' of ethnic channels in targeting an audience for which there already exist huge stocks of movies and television programmes, with the added advantage that picking up the European rights for Indian and Asian films was not expensive. Moreover, Bell argued, the focused nature of ethnic channels was a big advantage, both in terms of marketing the channel and pulling in advertis-

\footnotetext{
${ }^{15}$ In: Barry Flynn, 'Pan-European channels launch into phase two ', Television Business International, October 1992, p. 66.

${ }^{16}$ Television Business International, Yearbook '98, London 1998
} 
ers. ${ }^{17}$ The vast majority of these channels were licensed and based in London. Prime examples included the advertising-supported Chinese News \& Entertainment, broadcasting a compilation of prime-time programmes from Hong Kong, Mainland China, Taiwan and community programmes from major Chinese centres across Europe; its competitor, The Chinese Channel, launched in 1994; a private Japanese Channel JSTV, established in 1990; and Zee TV (1992), broadcasting in Urdu, Hindustani, Punjabi, Tamil, Bengali and English for the second and third generations of Asians.

Concluding this section, it can be said that truly pan-European channels did not reach significant audience shares during the first two decades of their existence. However, their presence was already extensive and both their audiences and the number of pan-European advertisers have grown continuously. In addition to the commercial pan-European offerings described, it was the satellitedistributed channels in European and non-European languages that established a European television market. This also included the offerings of national public service broadcasters, who increasingly put their national channel offerings on to satellite, established more foreign service channels and set up cross-border channels with a cultural mission, including, for example, TV5, 3SAT and ARTE. Undoubtedly, taken together all these channels came to establish audiences in Europe without regard to national frontiers.

\section{Transnational programming}

Programming constitutes the oldest form of transnationalization in television. Commercial television and transnational broadcasters accelerated the trend. The new commercial broadcasters in their start-up years were searching for cheap programmes, while later the proliferating demand for audio-visual software maintained the dependence on imports from other countries, especially the US. ${ }^{18}$ Transnational broadcasters, who have a distribution guarantee through their numerous local outlets, increased their in-house productions. Moreover, combined buying, achieving synergies and market power, increased the transnationalization of programming. Finally, transnational networks contributed much to the transnationalization of scheduling practices. Canal+ and CLT-UFA, for example, have both shared programming strategies throughout their networks.

While American fiction was still one of the biggest common denominators of European television markets in the 1980s and 1990s, a new popularity for indigenous productions on the part of commercial broadcasting stations came to be shared across Europe in the latter decade. In some cases, particularly in primetime, these came to replace American imports. Even so, as media journalist Gün Akuyz rightly pointed out in 1996, 'significant numbers of imports are still be-

\footnotetext{
${ }^{17}$ Nick Bell, 'Cultural Exceptions ', Television Business International, June 1994, p. 34

${ }^{18}$ See M. Bakke, Els de Bens and M. Kelly, 'Television content: Dallasification of culture? ', in: K. Siune and W. Truetzschler, Dynamics of media politics. Broadcast and electronic media in Western Europe, London 1992, pp. 89-91; and statistics in European Audiovisual Observatory, Statistical Yearbook '98, Strasbourg 1997
} 
ing placed in prominent slots. "19 The majority of top imports, shown in his March 1996 study for France, Italy, Spain, Germany, the Netherlands and the UK, were screened in and around prime-time. The TBI Yearbook 1997 reported Germany 's enthusiasm for US products, while the IP 's Television 95 revealed that the top 10 single programmes on several of France 's television channels included many American movies, and that the same was true for Germany, Greece, Italy, Norway, and Sweden. There also seemed to be some indications that American programmes especially appealed to younger audiences. With series such as Baywatch, Beverly Hills 90210 and Fresh Prince of Bel Air scheduled in the majority of European countries, commercial channels aimed to attract younger demographics. European television came to be characterized by simultaneous trends of a continued popularity of American programmes on the one hand and of home-produced programmes on the other. These, we argue, should be seen as complementary, not competing, programmes.

A second programming trend in the 1980s and 90s was that of a slowly rising programme trade between European countries. ${ }^{20}$ This happened by way of growing programme imports and exports within Europe; an increase in Englishlanguage products, including those of non-English-speaking countries; and through intensified European co-operations. Olivier-René Veillon, Chief Executive of TV France International, noted that in Europe the times were over when production companies concentrated on the growth of the indigenous market. From around 1995 onwards, he claimed, all big and small enterprises as well as most television channels were developing international strategies, with the French production industry, for example, already achieving $20 \%$ of its turnover abroad by 1996, selling rights to or co-producing with foreign companies. ${ }^{21} \mathrm{Un}$ fortunately, there are no extensive import and export statistics. However, reports in trade journals strongly suggest that programme trade in Europe was growing. The Kirch Group, for example, sold 3,200 hours of German-language programming in 1997, compared to just 1,000 hours five years earlier. According to Doris Kirch, due to increased production standards other countries were beginning to accept German products. Kommissar Rex even beat Emergency Room as Italy 's best foreign television series. Many German channels became involved in English-language co-productions or dubbed their programmes into English. RTL presented itself at the 1998 Mipcom in Cannes with 104 home-produced programmes, all synchronized into English.

Co-productions and co-financing had already been popular in Europe in the mid-1980s because of financial pressures in the industry. In the following decade, when international distribution became a newly tried means for European and American producers to offset production costs, the incentives became even

\footnotetext{
${ }^{19}$ Gün Akuyz, 'Play it again, Uncle Sam ', TV World, May 1996, p. 23f

${ }^{20}$ A distinction needs to be drawn, however, between large European countries equipped with sufficient revenues from advertising and licence fees - allowing for a high share of indigenous productions - and those smaller and less well-off European countries which can afford only a limited amount of home produced audio-visual software

${ }^{21}$ Blickpunkt: Film, 'Mit Deutschland in die Offensive gehen ', 35/1998
} 
stronger. Figures provided by ETS support this claim, as do reports in trade journals. 'International appeal ' was becoming an increasingly decisive factor for both European and American producers. For US companies, co-productions with European partners had the added attraction of being an effective way of getting around quotas, employed in some European countries to protect national and European productions. A continuation of the co-production trend, and with it an extension of the transnationalization of programming, seems inevitable. As Negrine and Papathanassopoulos have rightly pointed out: 'Whether programmes for international distribution are beamed across frontiers or coproduced, the effect is virtually the same. Audio-visual programmes have ceased to be primarily derived from one specific domestic cultural or national setting, and they are no longer simply intended for one domestic national audience '.22

Finally, transnationalization in programming proliferated in the form of proven genres, formats, and production and broadcasting practices. The new genre of 'infotainment ', for example, was exported from the US and taken on board by all European countries. After all, it was cheap and popular. As far as fiction is concerned, programmes of unknown genres were usually imported first, and later local adaptations were produced. By 1997, soaps, sitcoms and reality shows were copied locally in all European countries. Fiction about the supernatural (X-Files, Profilers, Pretenders, Nowhere-Men, Enemies, Millennium) followed. This kind of indirect programme import came to represent a major share of the overall programme offer of some channels. In the statistics it is labelled as indigenous production, ${ }^{23}$ regulatory agencies are generally prepared to consider it as domestic output, ${ }^{24}$ and with audiences too the finished programme registers as home-grown.

In the game sector, Family Feud (or Family Fortunes), for example, came to be shared by Belgium, France, Germany, Greece, Italy, the Netherlands, Poland, Portugal, Turkey and the UK. The Dating Game was shared by Denmark, Finland, France, Germany, Greece, Italy, the Netherlands, Poland, Portugal, Spain, Sweden, Turkey and the UK. Other widely shared Fremantle International game show formats included the Price is Right, Wheel of Fortune and Child 's Play. Australian-originated Grundy Worldwide, another major in selling game shows and serial formats produced Man $O$ Man in the UK, Sweden, Denmark, Nor-

\footnotetext{
${ }^{22}$ Negrine and Papathanassopoulos, 1990

${ }^{23}$ Note that, in general, figures provided by the channels - and also used by television yearbooksshould therefore be read with caution. Often these figures are used for lobbying purposes. TBI researchers Renaud and Dziadul also count local adaptations of game shows as domestic production.

${ }^{24}$ Note that according to Articles 4 and 5 of the Directive and Article 10 of the Convention, the demand for a majority of 'European " works is geared towards programmes 'excluding the time appointed to news, sport events, games, advertising, and tele-text services. 'The 'games 'concept, in both Articles 4 and 5 of the Directive and 10 of the Convention, refers to light entertainment programmes of low production values. This implies that officially it is not permitted to count format-based game shows as 'European works. '
} 
way, Spain, Portugal, France, Germany, the Netherlands, Italy and Belgium

In Europe, Dutch Endemol Entertainment and the UK Action Group emerged as leading format producers. The following table shows a selection of Endemol game show formats:

Table 1: Endemol game formats until 1997

\begin{tabular}{|c|c|c|c|c|c|}
\hline NL & Love Letters & Now or never & $\begin{array}{l}\text { Mini Playback } \\
\text { Show }\end{array}$ & All you need is love & Soundmix Show \\
\hline $\mathrm{BE}$ & Love Letters & Now or never & & All you need is love & Soundmix Show \\
\hline $\mathrm{DE}$ & Traumhochzeit & GlücksSpirale & $\begin{array}{l}\text { Mini Playback } \\
\text { Show }\end{array}$ & Nur die Liebe zählt & Soundmix Show \\
\hline ES & Una pareja feliz & & Menudo Show & $\begin{array}{l}\text { Lo que necesitas es } \\
\text { Amor }\end{array}$ & $\begin{array}{l}\text { Lluvia de Estrel- } \\
\text { las }\end{array}$ \\
\hline FR & & & & Parlez-moi d 'amour & \\
\hline IT & & & $\begin{array}{l}\text { Re per una } \\
\text { notte bambini }\end{array}$ & Stranamore & \\
\hline $\mathrm{NO}$ & Ja vi elsker & $\mathrm{Na}$ eller aldri & Smastjerner & & Stjamer i Sikte \\
\hline SE & Kär \& Galen & $\begin{array}{l}\text { Nu eller } \\
\text { aldrig }\end{array}$ & Smasstjarnorna & & $\begin{array}{l}\text { Sikta mot } \\
\text { Starnorna }\end{array}$ \\
\hline DK & Vidt forelsket & & & & \\
\hline FI & & & & Amorin Kaaret & \\
\hline PT & $\begin{array}{l}\text { Casados de } \\
\text { fresco }\end{array}$ & $\begin{array}{l}\text { Agora ou } \\
\text { Nunca }\end{array}$ & $\begin{array}{l}\text { Mini Chuva de } \\
\text { Estrelas }\end{array}$ & All you need is love & $\begin{array}{l}\text { Chuva de Estrel- } \\
\text { las }\end{array}$ \\
\hline PL & & & $\begin{array}{l}\text { Mini Playback } \\
\text { Show }\end{array}$ & & \\
\hline GB & & & & All you need is love & Stars in their eyes \\
\hline $\mathrm{HU}$ & & & & & Kifuto \\
\hline
\end{tabular}

Source: Endemol Entertainment

With the former's Big Brother reality show, audiences across Europe got a glimpse of the format concept. National newspapers reported on the show's success in other countries and pictures from several local-national adaptations were broadcast for comparison. Yet, by and large the format concept remains unnoticed by audiences in Europe, even though the trend, far from fizzling out, is actually accelerating.

Apart from genres and formats, production values and styles, such as the personalization of news, as well as scheduling practices were copied. Stripped scheduling and the practice of lead-in were both imported from the United States. The former has led towards a trend for standardizing the length of audiovisual products internationally. Programme formats, programme length, newly introduced genres and scheduling and production practices should all be considered when assessing transnationalization in programming. If adapted versions of game shows and series alone are taken into account in prime-time surveys, the 
amount of 'national' programming is diminished to a significant extent. Undoubtedly, the uniqueness of the originally national broadcasting markets has been watered down. Television has gradually become less national, more transnational; and this is true despite the newly found popularity of locally produced programmes.

\section{Conclusion}

The commercialization and transnationalization of television has led many politicians and opinion leaders all over Europe, and in particular those from small countries, to fear the possible socio-cultural consequences. Television is generally the primary source of information and entertainment for Europe 's citizens and hence a significant definer and transmitter of political, social and cultural values. Across the world, closed societies, denied information by their governments, are particularly believed to profit from unstoppable satellite signals. Moreover, as Preben Sepstrup rightly points out,

one might set up the hypothesis that diversified national background of television may diminish the risk of television consumption contributing to the development of culturally narrow, chauvinistic, provincial attitudes and increase the possibility of knowledge of an open mind toward other cultures and societies. ${ }^{25}$

Yet despite the positive information and cultural benefits of more open global media markets, the majority of researchers participating in the debate on transnationalization tend to emphasize negative effects, actual or potential. As a result of television 's commercialization, a decrease in quality has been expected and perceived, including a decline in pluralism and an increasing homogenization of audio-visual products. More specifically, the transnationalization of television is believed to result in a general loss of indigenous production capacity and an outlet for national identity. Small (national) markets, it is claimed, are incapable of competing in a transnational market.

Monroe Price and Marit Bakke both argue that television is no longer a means for promoting national integration and identity building. ${ }^{26}$ This article has shown that satellite television draws together audiences who share a language across national borders. In addition, for the growing number of immigrants and members of ethnic communities in Europe, satellite television, with its offer of plurality and contact with the 'home ' country, cannot but lessen the importance of 'national' channels. Ien Ang is one of the few researchers who mention the new possibility satellite television affords to geographically dispersed people,

\footnotetext{
${ }^{25}$ Preben Sepstrup, 'Implications of current developments in west European broadcasting ', Media, Culture and Society, Vol. 11/1989, p. 46.

${ }^{26}$ Monroe Price, Television, the public sphere, and national identity, Oxford 1996; Marit Bakke, 'Culture at Stake ', in: D. McQuail and K. Siune, New media politics. Comparative perspectives in western Europe, London 1986, pp. 130-51
} 
offering 'opportunities of new forms of bonding and solidarities, new ways of forging cultural communities. ${ }^{27}$

Yet apart from people who share a common language, there has not yet been much evidence that new communities can be established in this way. The example of MTV might even suggest the contrary. It is probably too early to draw any firm conclusions in this respect. Socio-cultural changes usually occur gradually, as do changes in television viewing habits. The importance of thematic channels has been growing, albeit slowly; and with the strengthening of the European Union, especially now with the newly introduced single currency, one can envisage the possibility of a stronger sense of European identity emerging. This in turn could affect television consumption. After all, the pan-European market, with channels like Euronews and Eurosport, already exists.

At the same time, while language borders seem to have replaced traditional national borders in television viewing, local channel offerings, targeting an area smaller than the national one, have become increasingly popular. One example of a local channel overtaking a national channel in popularity took place in Sweden, where after a reorganization of the public service broadcaster in 1987, TV2, distributing regionally produced programmes and regional information, became the more popular channel. In the following decade, the IP 's 1998 television yearbook reported that regional public service channels in Spain had gone up from $15.1 \%$ audience share in 1994 to $17.4 \%$ in 1997. The French regional public service channel FR3 had a 17.3\% audience share in 1997; and in Germany the regional programmes of the public service ARD had a $12 \%$ audience share in the same year, an increase of more than $50 \%$ over a four year period. These are significant audience shares which call into question the exclusive bi-polar categorization of national versus foreign, upheld so strongly by numerous media researchers and personnel of television channels alike.

As far as reception is concerned, both this article and other research, for example that of Daniel Miller, ${ }^{28}$ have shown that audiences tend to assess locally adapted formats as indigenous and value them highly as such. Moreover, research by Gurevitch, Levy and Roeh on convergences and diversities in the globalization of television news led them to conclude that 'while the images may have global currency, the meanings given to them may not necessarily be shared globally. ${ }^{29}$ These arguments correspond to those of Ulrich Beck, Roland Robertson, Ulf Hannerz and many others in the tradition of cultural theory. They all recognize the processes of transnationalization and globalization, but deny the assumption of an increasing universalization in terms of life-styles,

\footnotetext{
${ }^{27}$ Ien Ang, 'Culture and communication: Towards an ethnographic critique of media consumption in the transnational media system ', European Journal of Communication, Vol. 5/1990, p. 255.

${ }^{28}$ Miller 's research findings are referred to in David Morley, 'Where the global meets the local: notes from the sitting room. ', Screen, 32/1, Spring 1991, p. 9f.

${ }^{29}$ M. Gurevitch, M. R. Levy and I. Roeh, The global newsroom: convergences and diversities in the globalization of television news ', in: P. Dahlgren and C. Sparks, Communication and Citizenship. Journalism and the public sphere, London 1991, p. 214.
} 
cultural symbols and transnational patterns of behaviour. Globalization, they claim, not only creates transnational social relations and spaces, but it also enhances the status of local cultures and creates third cultures.

It is very likely that the reception of television programmes creates 'glocal " products. There is no hard evidence that existing cultural differences will simply be eroded by television 's transnationalization. Yet at the same time it is not unlikely that identities will shift in the age of transnational communication. However, what kinds of identity will emerge will remain uncertain for some time to come.

The thrust of this article has been to emphasize the transnational framework in European television fostered by international media companies spanning broadcasting networks across the world. They have strongly contributed to experience being unified beyond localities and to an increasing amount of content being shared by a growing number of people. To this extent it is possible to speak of a 'European television market ' emerging in the final two decades of the twentieth century, though not to predict the precise forms it may take in the future. 